Prepared in cooperation with the National Water Quality Assessment Program and the Georgia Department of Agriculture

\title{
Analysis of the Herbicide Diuron, Three Diuron Degradates, and Six Neonicotinoid Insecticides in Water- Method Details and Application to Two Georgia Streams
}

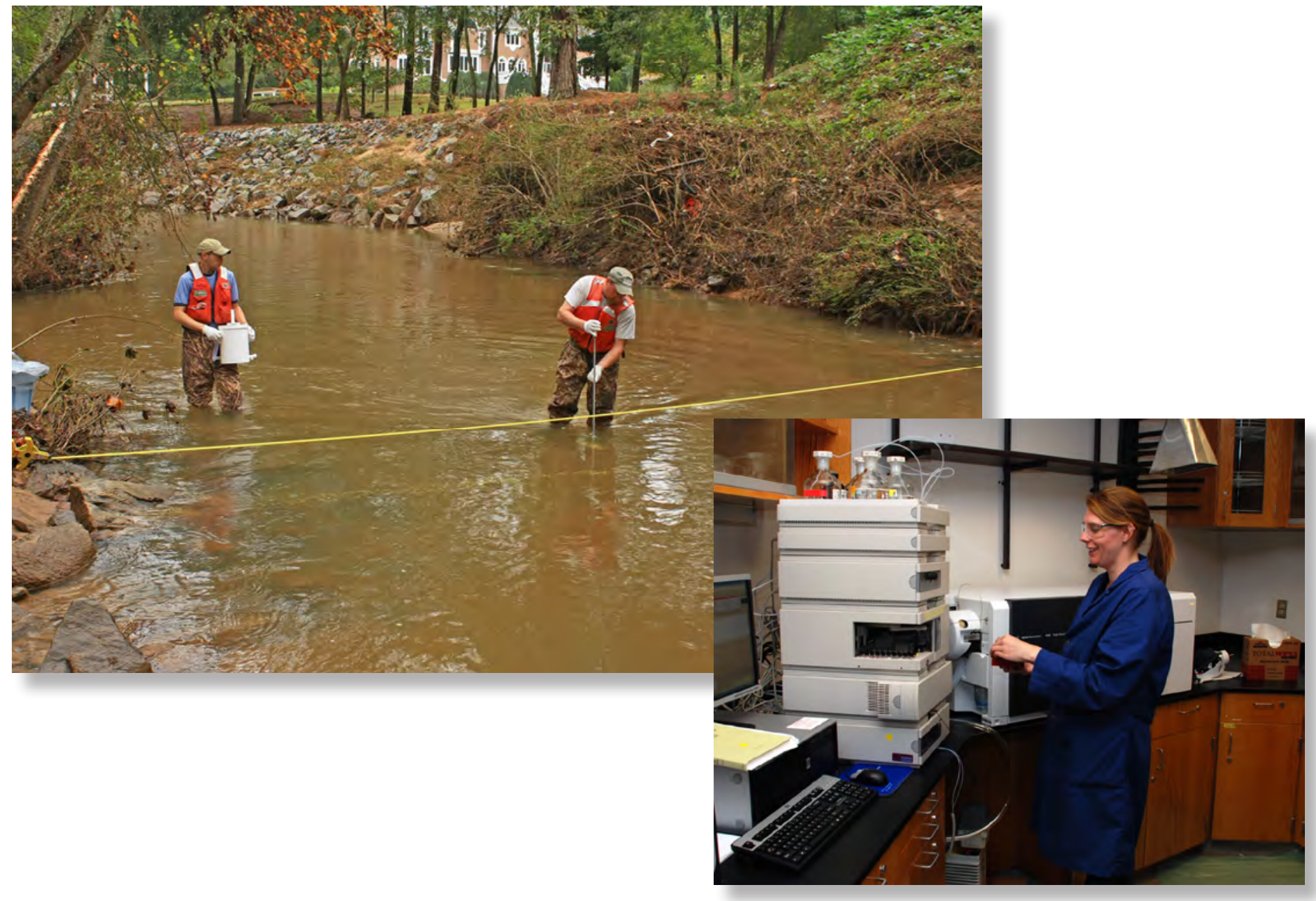

Scientific Investigations Report 2012-5206 
Cover: Photograph of field work by Alan Cressler, U.S. Geological Survey, Georgia Water Science Center.

Photograph of laboratory by Cathy Munday, U.S. Geological Survey, California Water Science Center. 


\section{Analysis of the Herbicide Diuron, Three Diuron Degradates, and Six Neonicotinoid Insecticides in Water-Method Details and Application to Two Georgia Streams}

By Michelle L. Hladik and Daniel L. Calhoun

Prepared in cooperation with the National Water Quality Assessment Program and the Georgia Department of Agriculture

Scientific Investigations Report 2012-5206 


\title{
U.S. Department of the Interior \\ KEN SALAZAR, Secretary \\ U.S. Geological Survey \\ Marcia K. McNutt, Director
}

\author{
U.S. Geological Survey, Reston, Virginia: 2012
}

For more information on the USGS - the Federal source for science about the Earth, its natural and living resources, natural hazards, and the environment, visit http://www.usgs.gov or call 1-888-ASK-USGS.

For an overview of USGS information products, including maps, imagery, and publications, visit http://www.usgs.gov/pubprod

To order this and other USGS information products, visit http://store.usgs.gov

Any use of trade, product, or firm names is for descriptive purposes only and does not imply endorsement by the U.S. Government.

Although this report is in the public domain, permission must be secured from the individual copyright owners to reproduce any copyrighted materials contained within this report.

Suggested citation:

Hladik, M.L. and Calhoun, D.L, 2012, Analysis of the herbicide diuron, three diuron degradates, and six neonicotinoid insecticides in water-Method details and application to two Georgia streams: U.S. Geological Survey Scientific Investigations Report 2012-5206, 10 p. Available at http://pubs.usgs.gov/sir/2012/5206. 


\section{Contents}

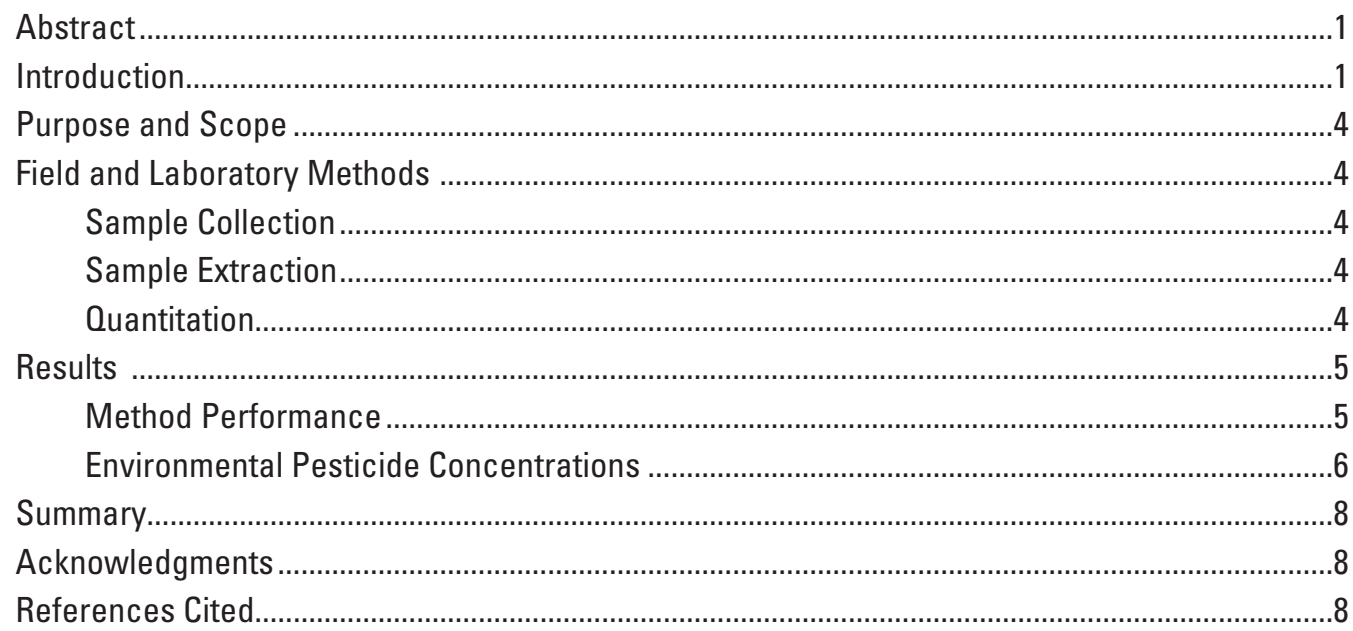

\section{Figures}

1. Image showing chemical structures of the pesticides and degradates analyzed for in the method

\section{Tables}

1. CAS Registry number, molecular weight, solubility, octanol-water partition coefficient (Kow) and hydrolysis half-life and laboratory parameter code for each pesticide and degradate

2. Multiple-reaction-monitoring mode parameters for pesticides analyzed by LC/MS/MS

3. Analytical method mean percentage recovery at 20 nanograms per liter (ng/L) of spike concentration in American River water, relative standard deviation, and method detection limits

4. Dissolved pesticide concentrations measured in samples collected at sites located in Georgia, October 2011 through April 2012 


\section{Conversion Factors and Abbreviations}

SI to Inch/Pound

\begin{tabular}{|c|c|c|}
\hline Multiply & By & To obtain \\
\hline \multicolumn{3}{|c|}{ Area } \\
\hline square kilometers $\left(\mathrm{km}^{2}\right)$ & 0.3861 & square miles $\left(\mathrm{mi}^{2}\right)$ \\
\hline \multicolumn{3}{|c|}{ Length } \\
\hline centimeter (cm) & 0.3937 & inch (in.) \\
\hline micrometer $(\mu \mathrm{m})$ & $3.937 \times 10^{-5}$ & inch (in.) \\
\hline millimeter (mm) & 0.03937 & inch (in.) \\
\hline meter $(\mathrm{m})$ & 39.37 & inch (in.) \\
\hline \multicolumn{3}{|c|}{ Mass } \\
\hline gram (g) & 0.03527 & ounce, avoirdupois (oz) \\
\hline kilogram (kg) & 2.205 & pound, avoirdupois (lb) \\
\hline microgram $(\mu \mathrm{g})$ & $3.527 \times 10^{-8}$ & ounce, avoirdupois (oz) \\
\hline milligram (mg) & $3.527 \times 10^{-5}$ & ounce, avoirdupois (oz) \\
\hline nanogram (ng) & $3.527 \times 10^{-11}$ & ounce, avoirdupois (oz) \\
\hline \multicolumn{3}{|c|}{ Pressure } \\
\hline kilopascal (kPa) & 0.1450 & pound-force per inch (lbf/in) \\
\hline \multicolumn{3}{|c|}{ Volume } \\
\hline liter (L) & 0.2642 & gallon (gal) \\
\hline microliter $(\mu \mathrm{L})$ & $2.642 \times 10^{-7}$ & gallon (gal) \\
\hline milliliter (mL) & 0.000264 & gallon (gal) \\
\hline
\end{tabular}

Temperature in degrees Celsius $\left({ }^{\circ} \mathrm{C}\right)$ may be converted to degrees Fahrenheit $\left({ }^{\circ} \mathrm{F}\right)$ as follows:

$$
{ }^{\circ} \mathrm{F}=\left(1.8 \times{ }^{\circ} \mathrm{C}\right)+32
$$




\section{Conversion Factors and Abbreviations}

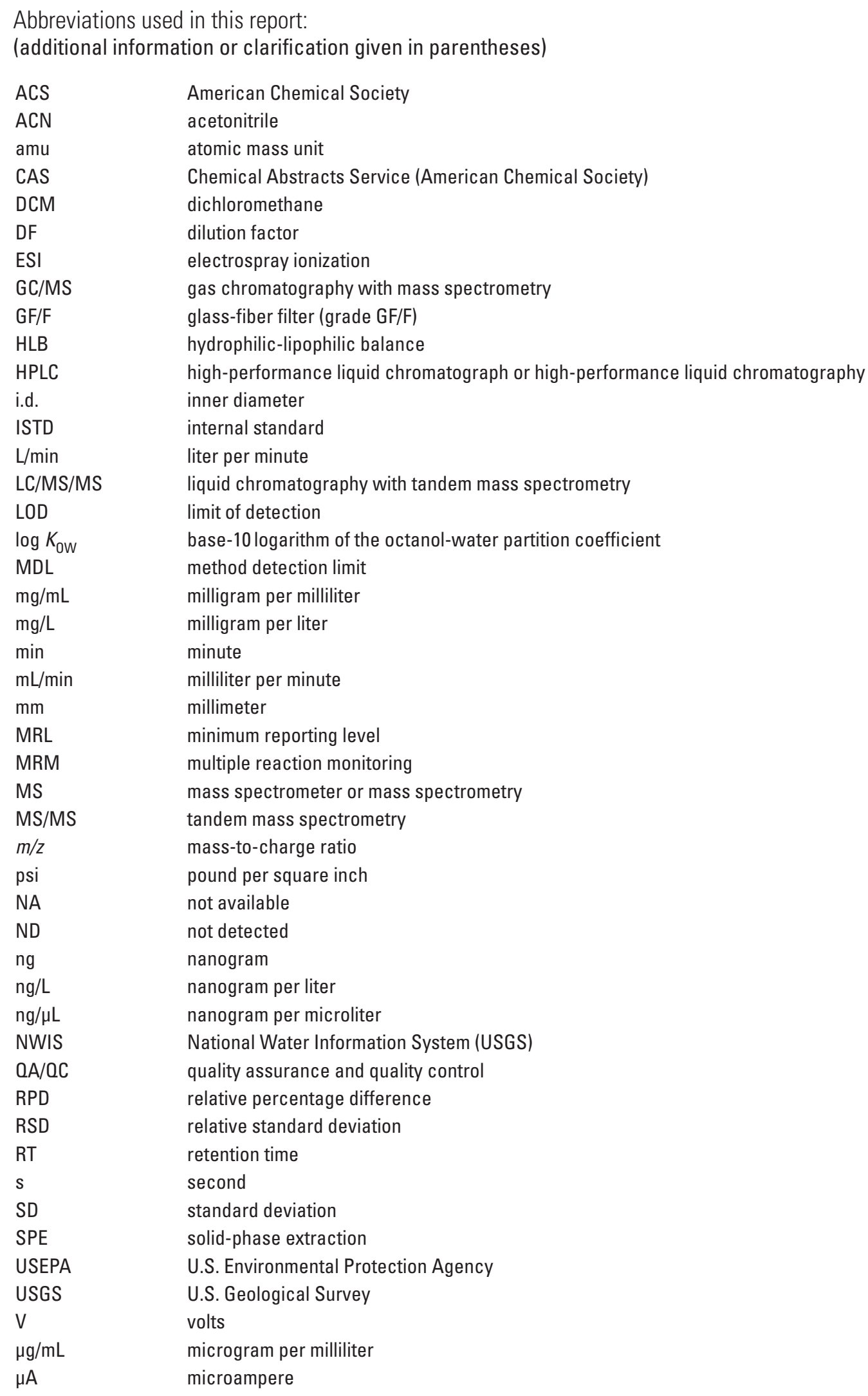


This page intentionally left blank. 


\title{
Analysis of the Herbicide Diuron, Three Diuron Degradates, and Six Neonicotinoid Insecticides in Water-Method Details and Application to Two Georgia Streams
}

\author{
By Michelle L. Hladik and Daniel L. Calhoun
}

\begin{abstract}
A method for the determination of the widely used herbicide diuron, three degradates of diuron, and six neonicotinoid insecticides in environmental water samples is described. Filtered water samples were extracted by using solid-phase extraction (SPE) with no additional cleanup steps. Quantification of the pesticides from the extracted water samples was done by using liquid chromatography with tandem mass spectrometry (LC/MS/MS).

Recoveries in test water samples fortified at 20 nanograms per liter (ng/L) for each compound ranged from 75 to 97 percent; relative standard deviations ranged from 5 to 10 percent. Method detection limits (MDLs) in water ranged from 3.0 to $6.2 \mathrm{ng} / \mathrm{L}$ using LC/MS/MS. The method was applied to water samples from two streams in Georgia, Sope Creek and the Chattahoochee River. Diuron and 3,4-dichloroaniline (3,4-DCA) were detected in 100 and 80 percent, respectively, of the samples from the Chattahoochee River, whereas Sope creek had detection frequencies of 15 percent for diuron and 31 percent for 3,4-DCA. Detection frequencies for the neonicotinoid insecticide, imidacloprid, were 60 percent for the Chattahoochee River and 85 percent for Sope Creek. Field matrix-spike recoveries for each compound, when averaged over four water samples, ranged from 79 to 100 percent. The average percentage difference between replicate pairs for all compounds detected in the field samples was 10.1 ( \pm 4.5$)$ percent.
\end{abstract}

\section{Introduction}

The U.S. Geological Survey (USGS) Organic Chemistry Laboratory in Sacramento, California (Sacramento Laboratory), has developed robust analytical methods for a broad array of current-use and legacy pesticides in water, sediment, and tissue by using gas chromatography/mass spectrometry (GC/MS) and gas chromatography tandem mass spectrometry (GC/MS/MS) (Hladik and others, 2008, 2009; Smalling and Kuivila, 2008; Smalling and others, 2010). The use of only GC-based methods, however, has limitations because a certain subset of pesticides cannot be analyzed by GC. These pesticides are not volatile enough for GC or degrade in a hot GC injection port, which makes them potential candidates for liquid chromatography-based analysis.

The Sacramento Laboratory has targeted a set of pesticides of local and national interest as the highest priority for liquid chromatography with tandem mass spectrometry (LC/MS/MS) methods development. The herbicide, diuron, is one of the most frequently used herbicides in California with 264,000 kg applied in 2010 (ranking number 33 for kilograms applied). Diuron (3-(3,4-dichlorophenyl)-1,1-dimethylurea) is applied in agricultural areas (alfalfa, citrus), as well as for use on "rights of way," such as highways, which makes its use ubiquitous throughout the State (California Department of Pesticide Regulation, 2010). Diuron is one of the most frequently detected pesticides in water in the San Francisco Bay-Delta and nearby areas (Guo and others, 2010). Concentrations of diuron can reach several thousand $\mathrm{ng} / \mathrm{L}$, as has been documented in samples collected in spring when runoff from the Bay-Delta is high, from the State Water Project distribution system (California Department of Water Resources, 2010). Diuron is also widely used on agricultural crops across the United States, ranking $22^{\text {nd }}$ in 2007 in terms of mass of active ingredient applied (0.9-1.8 million kg; U.S. Environmental Protection Agency, 2011).

Elevated levels of diuron in water could lead to aquatic toxicity and can have human health implications (U.S. Environmental Protection Agency, 2003a). Diuron is moderately toxic to fish and highly toxic to aquatic invertebrates (Turner, 2003). In addition to diuron, the three primary diuron degradates are included in the analysis method 


\section{Analysis of the Herbicide Diuron and Six Neonicotinoid Insecticides in Water-Method Details and Application}

described in this report [DCPMU (3-(3,4-dichlorophenyl)-1methylurea), DCPU (3,4-dichlorophenylurea), and 3,4-DCA (3,4-dichloroaniline)] (figure 1; table 1). The occurrence of diuron degradates in the aquatic environment is of concern because, in some cases, the degradates are more toxic than the parent compounds (Tixier and others, 2000). Additionally because some degradates are more stable than diuron, they can persist longer in the environment (table 1). Diuron can also be a disinfection by-product precursor; under certain water-treatment conditions, diuron can form $N$-nitrosodimethyl amine (NDMA) (Chen and Young, 2008), which is a class B2 carcinogen (reasonably considered to be a human carcinogen; U.S. Environmental Protection Agency 2010).

Neonicotinoid insecticides are the second class of compounds that are of interest. This class of compounds have a common mode of action that affects the central nervous system of insects, are increasing in use throughout the United States, and have been linked to colony collapse disorder in bees (CRS, 2007). This group includes acetamiprid, clothianidin, dinotefuran, imidacloprid, thiacloprid and thiamethoxam (figure 1; table 1). Imidacloprid is the most widely used neonicotinoid in the United States and has a broad range of uses; other neonicotinoids, such as clothianidin, are used for more-specialized applications such as seed coatings on corn (U.S. Environmental Protection Agency, 2003b). Imidacloprid, and other neonictinoids, have increasingly been used over much of the Eastern United States during the previous decade to treat Eastern and Carolina Hemlocks for infestation by the hemlock wooly adelgid (Cowles, 2009) and ash trees for the emerald ash borer (Kreutzweiser and others, 2007). Possible leaching of these insecticides to surface waters and transport by way of leaf litter has been of concern. Recently, thiamethoxam has been linked to decreased survival in honeybees (Henry and others, 2012) and imidacloprid has been linked to reduced growth in bumble bees (Whitehorn and others, 2012). Bees are essential pollinators of agricultural crops, and their recent decline in population has triggered an increase in research to understand and combat the decline (vanEngelsdorp and others, 2009). Monitoring data for imidacloprid and other neonicotinoinds in environmental waters are scarce; analysis of the neonicotinoid insecticides would help in determining their fate in the environment and possible implications to biota, which include pollinators and aquatic invertebrates.

Table 1. CAS Registry number, molecular weight, solubility, octanol-water partition coefficient $\left(\mathrm{K}_{\mathrm{ow}}\right)$ and hydrolysis half-life and laboratory parameter code for each pesticide and degradate.

[This report contains Chemical Abstracts Service Registry Numbers (CASRN), which is a Registered Trademark of the American Chemical Society. Chemical Abstracts Service (CAS) recommends the verification of the CASRNs through CAS Client Services. Solubility, $\log \mathrm{K}_{\mathrm{ow}}$, and hydrolysis data were obtained from the Pesticide Properties Database (University of Hertforshire, 2011). The five-digit parameter codes are used by the U.S. Geological Survey to uniquely identify a specific constituent or property in the National Water Information System (NWIS) database. Abbreviations: amu, atomic mass units, mg/L, milligrams per liter; $\log \mathrm{K}_{\mathrm{ow}}$, octanol-water partition coefficient; NA, not available]

\begin{tabular}{lcccccc}
\hline \multicolumn{1}{c}{ Compound } & $\begin{array}{c}\text { CAS } \\
\text { number }\end{array}$ & $\begin{array}{c}\text { Molecular } \\
\text { weight } \\
\text { (amu) }\end{array}$ & $\begin{array}{c}\text { Water } \\
\text { solubility } \\
\text { (mg/L) }\end{array}$ & $\begin{array}{c}\text { Log } \\
\text { Kow }\end{array}$ & $\begin{array}{c}\text { Aqueous } \\
\text { dissipation } \\
\text { half life } \\
\text { (days) }\end{array}$ & $\begin{array}{c}\text { Parameter } \\
\text { code }\end{array}$ \\
\hline \multicolumn{7}{c}{ Diuron and degradates } \\
\hline Diuron & $330-54-1$ & 233.1 & 35.6 & 2.87 & 8.8 & 66598 \\
DCPMU & $3567-62-2$ & 219.1 & 490 & NA & NA & 68231 \\
DCPU & $2327-02-8$ & 205 & 940 & 2.35 & NA & 68226 \\
3,4-DCA & $95-76-1$ & 162 & 580 & 2.69 & NA & 66584 \\
\hline & \multicolumn{7}{c}{ Neonicotinoid insecticides } & & \\
\hline Acetamiprid & $135410-20-7$ & 222.7 & 2,950 & 0.8 & 4.7 & 68302 \\
Clothianidin & $210880-92-5$ & 249.7 & 340 & 0.91 & 40.3 & 68221 \\
Dinotefuran & $165252-70-0$ & 202.1 & 39,800 & -0.55 & NA & 68379 \\
Imidacloprid & $138261-41-3$ & 255.7 & 610 & 0.57 & 30 & 68426 \\
Thiacloprid & $111988-49-9$ & 252.7 & 184 & 1.26 & 8.5 & 68485 \\
Thiamethoxam & $153719-23-4$ & 291.7 & 4,100 & -0.13 & 30.6 & 68245 \\
\hline
\end{tabular}



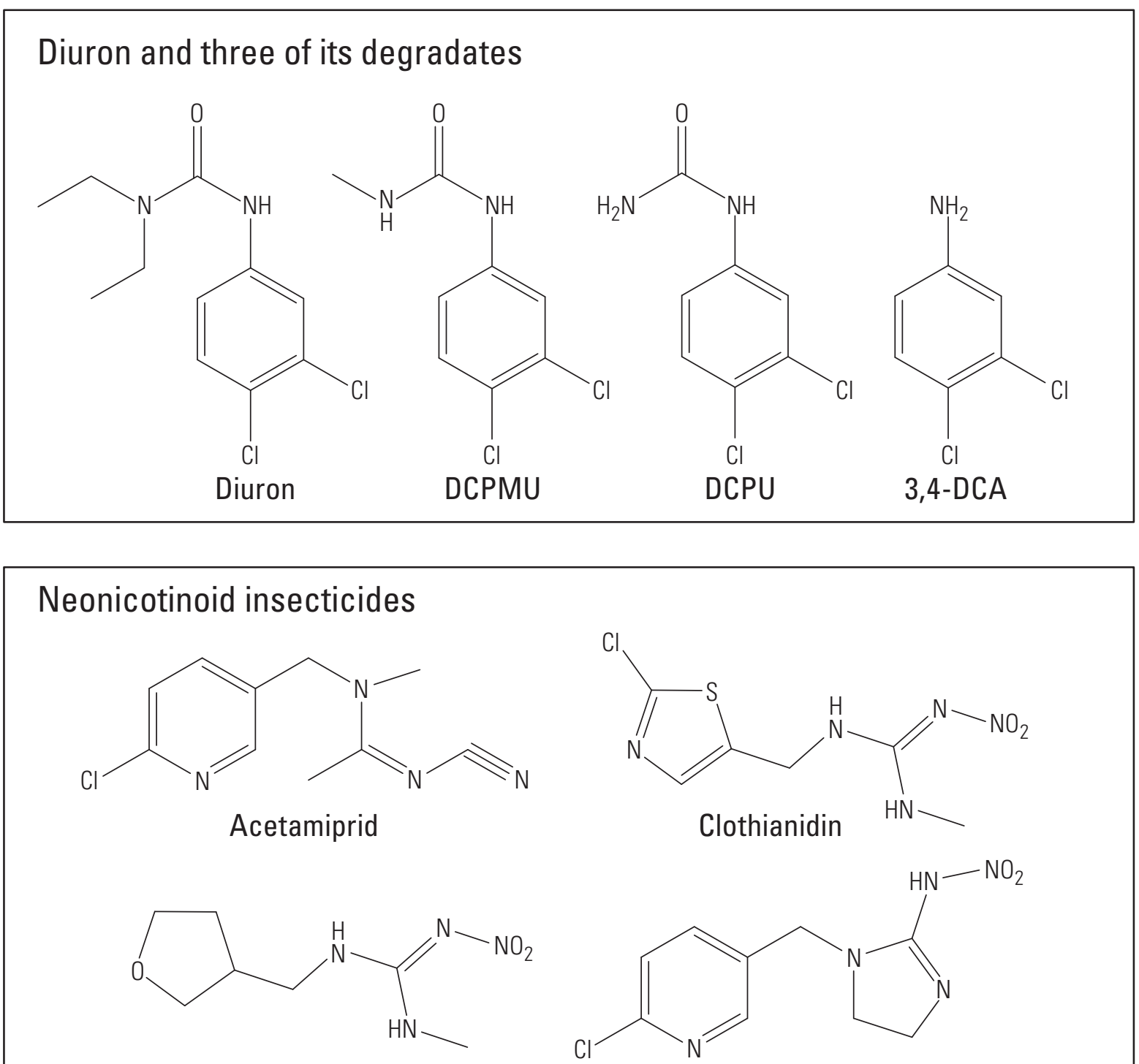

Dinotefuran

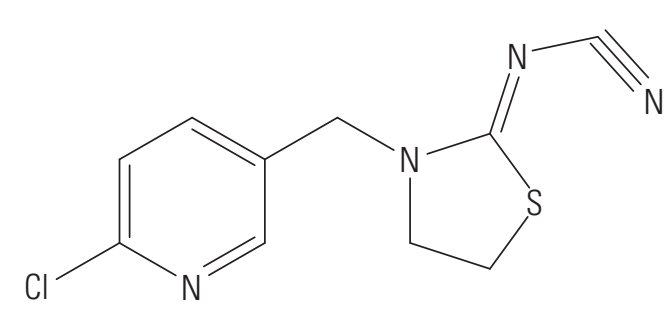

Thiacloprid

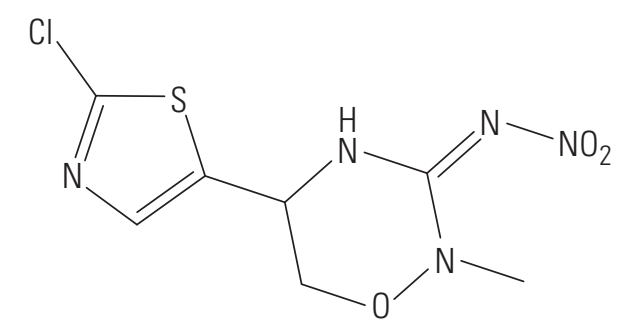

Thiamethoxam

Figure 1. Chemical structures of the pesticides and degradates analyzed for in the method. 


\section{Analysis of the Herbicide Diuron and Six Neonicotinoid Insecticides in Water-Method Details and Application}

\section{Purpose and Scope}

The purpose of this report is to describe a method for the extraction and quantification of selected pesticides and degradates from water samples and to present data from the application of this method to water samples collected from two streams in Georgia. The methods described in this report were developed by the USGS Sacramento Laboratory to analyze the herbicide diuron and three of its degradates, along with six neonicotinoid insecticides, in filtered water samples. The compounds included in this method are listed in table 1, including their Chemical Abstracts Service (CAS) Registry numbers, molecular weights, and USGS laboratory parameter codes. The extraction of the target compounds from 1-L filtered water samples is achieved with solid-phase extraction (SPE), and all target compounds are separated, detected, identified and quantified LC/MS/MS. The performance of this method was evaluated by using MDLs, surrogate recoveries, field and laboratory spiked recoveries, and field and laboratory blanks. This method was applied to stream samples from two locations in Georgia. The Georgia sampling is ongoing. Further interpretation of the Georgia data will occur upon completion of the project.

\section{Field and Laboratory Methods}

\section{Sample Collection}

For the described analysis method, water samples are collected in the field into 1-L amber glass bottles by using the methods outlined by U.S. Geological Survey (2006) and Ward and Harr (1990). Samples are chilled immediately, shipped to the Sacramento Laboratory, and refrigerated at $4^{\circ} \mathrm{C}$ until extraction (within 48 hours of collection). Samples are filtered either in the field (preferred) or in the laboratory using a baked 0.7-mm nominal pore size GF/F-grade glass-fiber filters (Whatman, Piscataway, New Jersey).

\section{Sample Extraction}

Each filtered water sample is spiked with recovery surrogate standards, monuron (Chem Service, West Chester, Pennsylvania) and (or) imidacloprid- $d_{4}$ (Cambridge Isotope Laboratories, Andover, Massachusetts). The surrogates that were chosen as compounds are similar in structure to the target analytes; deuterated imidacloprid is not found in the environment, and monuron was canceled for use in the United States in 1977 (U.S. Environmental Protection Agency, 1998). The sample is loaded onto a precleaned Oasis HLB SPE (6 mL, 500 mg; Waters, Milford, Massachusetts) cartridge that has been cleaned with one column volume of dichloromethane followed by one column-volume of acetone and two column-volumes of deionized water. The water sample is pumped through the SPE cartridge at a flow rate of $10 \mathrm{~mL} / \mathrm{min}$; the SPE cartridge is then dried under carbon dioxide for approximately $1 \mathrm{hr}$ or until the SPE sorbent is dry. The analytes are eluted into a clean glass concentrator tube by using $10 \mathrm{~mL}$ of 50:50 DCM:acetone. The eluent is evaporated to less than $0.5 \mathrm{~mL}$ in a fume hood by using a gentle stream of dry nitrogen, solvent-exchanged into acetonitrile (ACN), and further evaporated to less than $0.2 \mathrm{~mL}$. The internal standard $\left({ }^{13} \mathrm{C}_{3}\right.$-caffeine, Cambridge Isotope Laboratories) is then added (10 $\mu \mathrm{L}$ of a $1-n g / \mu \mathrm{L}$ solution). The sample extracts are stored in a freezer at $-20^{\circ} \mathrm{C}$ until analysis (up to 30 days).

\section{Quantitation}

Neat target pesticides—-diuron, acetamiprid, clothianidin, dinotefuran, imidacloprid, thiacloprid and thiamethoxamwere obtained from the U.S. Environmental Protection Agency Pesticide Repository (Ft. Meade, Maryland); 3,4-DCA was purchased from Chem Service (West Chester, Pennsylvania); and, DCPMU and DCPU were purchased from Dr.

Ehrenstorfer GmbH (Augsburg, Germany). Compounds were dissolved into acetone to make concentrated stock solutions ( $1 \mathrm{mg} / \mathrm{mL}$ ) which were further diluted to make appropriate standards in ACN.

Aliquots of the sample extracts $(10 \mu \mathrm{L})$ are injected, and the compounds, separated on an Agilent (Palo Alto, California) 1100 HPLC coupled to a 6430 tandem MS system with a Zorbax Eclipse XDB-C18 column $(2.1 \mathrm{~mm} \times 150 \mathrm{~mm}$ $\times 3.5 \mathrm{~mm}$; Agilent). The column flow rate is $0.6 \mathrm{~mL} / \mathrm{min}$, and the column temperature us $30^{\circ} \mathrm{C}$. The mobile phases are ACN (A channel) and 5 millimoloar (mM) formic acid in water (B channel). The column gradient is 2 percent: 98 percent (A:B) from 0 to $2 \mathrm{~min}$; 2 to 4 min increase to 50 percent : 50 percent (A:B), hold for $3 \mathrm{~min}$ (7 min); 7 to $7.5 \mathrm{~min}$ decrease to 2 percent : 98 percent (A:B), hold for 4.5 min (12 min). MS/MS conditions are electrospray (ESI) ionization, positive mode, drying gas temperature $350^{\circ} \mathrm{C}$, drying gas flow $10 \mathrm{~L} / \mathrm{min}$, capillary voltage $4,000 \mathrm{~V}$, and nebulizer $40 \mathrm{psi}$. Data are collected in the multiple-reaction-monitoring (MRM) mode; details of the MRM parameters are given in table 2. 
Table 2. Multiple-reaction-monitoring mode parameters for pesticides analyzed by LC/MS/MS.

[Abbreviations: LC/MS/MS, liquid chromatography with tandem mass spectrometry; m/z, mass-to-charge ratio; V, Volts; min, minute]

\begin{tabular}{|c|c|c|c|c|c|c|c|}
\hline Compound & $\begin{array}{l}\text { Precursor } \\
\text { ion } \\
(\mathrm{m} / \mathrm{z})\end{array}$ & $\begin{array}{l}\text { Quantitation } \\
\text { ion } \\
(\mathrm{m} / \mathrm{z})\end{array}$ & $\begin{array}{l}\text { Qualitative } \\
\text { ion } \\
(\mathrm{m} / \mathrm{z})\end{array}$ & $\begin{array}{c}\text { Fragmentor } \\
\text { voltage } \\
\text { (V) }\end{array}$ & $\begin{array}{c}\text { Quantitation } \\
\text { ion collision } \\
\text { energy } \\
\text { (V) }\end{array}$ & $\begin{array}{c}\text { Qualitative } \\
\text { ion collision } \\
\text { energy } \\
\text { (V) }\end{array}$ & $\begin{array}{l}\text { Retention } \\
\text { time } \\
\text { (min) }\end{array}$ \\
\hline \multicolumn{8}{|c|}{ Diuron and degradates } \\
\hline Diuron & 233 & 72 & 160 & 106 & 20 & 24 & 7.4 \\
\hline DCPU & 205 & 127 & 162 & 116 & 28 & 12 & 6.5 \\
\hline DCPMU & 219 & 127 & 162 & 106 & 32 & 12 & 6.9 \\
\hline 3,4-DCA & 162 & 127 & 109 & 123 & 20 & 32 & 7.7 \\
\hline $\begin{array}{l}\text { Monuron } \\
\text { (recovery surrogate) }\end{array}$ & 199 & 72 & 126 & 96 & 12 & 24 & 6.5 \\
\hline \multicolumn{8}{|c|}{ Neonicotinoid insecticides } \\
\hline Acetamiprid & 223 & 126 & 56 & 45 & 20 & 12 & 6.0 \\
\hline Clothianidin & 250 & 169 & 132 & 79 & 8 & 12 & 5.8 \\
\hline Dinotefuran & 203 & 113 & 129 & 45 & 4 & 4 & 5.1 \\
\hline Imidacloprid & 256 & 209 & 89 & 89 & 12 & 12 & 5.9 \\
\hline $\begin{array}{l}\text { Imidacloprid- } d 4 \\
\text { (recovery surrogate) }\end{array}$ & 260 & 213 & 179 & 91 & 12 & 16 & 5.9 \\
\hline Thiacloprid & 253 & 126 & 90 & 45 & 16 & 40 & 6.3 \\
\hline Thiamethoxam & 292 & 211 & 181 & 84 & 8 & 20 & 5.6 \\
\hline \multicolumn{8}{|c|}{ Internal standard } \\
\hline${ }^{13} \mathrm{C}_{3}$-Caffeine & 198 & 140 & 112 & 121 & 16 & 24 & 5.3 \\
\hline
\end{tabular}

\section{Results}

\section{Method Performance}

Method performance was evaluated for recovery by using water collected from the Lower American River (California) that was spiked at $100 \mathrm{ng} / \mathrm{L}$ with the target compounds. The American River water was used in place of laboratory reagent water because this water better represents real-world conditions. The American River carries snowmelt and drainage from the Sierra Nevada Mountains, and the water is detained by a series of dams upstream of the collection point, which makes this matrix water consistent in composition; the river has low suspended sediment and low dissolved organic carbon (less 1 percent) and has not had any pesticide detections in blank samples of the target compounds during the development of this method. Because all initial recoveries of the target analytes (listed in table 2) were greater than 70 percent (data not shown), all the compounds were included in the final method for analysis of environmental water samples.
Final method recoveries and MDLs were determined by using seven samples of American River water spiked at $20 \mathrm{ng} / \mathrm{L}$ (table 3). The MDL is defined as the minimum concentration of a substance that can be measured and reported with 99-percent confidence that the compound concentration is greater than zero; MDLs were determined according to the procedure outlined by the U.S. Environmental Protection Agency in 40 CFR 136, Appendix B, assuming a 1-L (water) sample (U.S. Environmental Protection Agency, 1997).

$$
\mathrm{MDL}-\mathrm{S} \times \mathrm{t}(\mathrm{n}-1,1-\alpha=0.99)
$$

where

$S$ is the standard deviation of replicate analyses, in nanogram per liter or microgram per gram, at the lowest spike concentration;

$t(n-1,1-\alpha=0.99)$ is the Student's t-value for the 99 percent confidence level with $\mathrm{n}$-1degrees of freedom. 


\section{Analysis of the Herbicide Diuron and Six Neonicotinoid Insecticides in Water-Method Details and Application}

The MDLs in table 3, which were determined by using the previous equation, ranged from $3.0 \mathrm{ng} / \mathrm{L}$ (DCPMU) to $6.2 \mathrm{ng} / \mathrm{L}$ (clothianidin). Average method recoveries shown in table 3 ranged from 75 to 99 percent, with relative standard deviations (RSDs) of 5 to 10 percent.

This analytical method was then applied to environmental samples. Water samples were collected from two sites in Georgia; 10 samples from the Chattahoochee River near Whitesburg, Georgia, and 13 samples from Sope Creek near Marietta, Georgia. Additional samples were collected for quality assurance and quality control (QA/QC).

Dissolved-pesticide concentrations were validated against a comprehensive set of quality-control parameters that included laboratory and field blanks, matrix spikes, matrix spike replicates, replicate field samples, and surrogate recovery. Laboratory and field blanks were analyzed: there was one field blank at each site and two laboratory blanks. No target compounds were detected in any of the blanks. The recovery surrogate, imidacloprid- $\mathrm{d}_{4}$, was used to assess the efficiency of sample extraction; mean percent recovery ( \pm standard deviation) for all samples analyzed (including QC samples) was $87.6 \pm 9.6$ percent, and no single sample had lower than 75 -percent recovery. Thirteen sets of replicate field samples had relative percentage differences of less than 16 percent for all pesticides detected; average percentage difference for the replicate pairs was 10.1 percent $( \pm 4.5)$. Four field matrix spikes were analyzed, and average recoveries ranged from 79 to 100 percent. Historically, the dissolved organic carbon content of these streams (in 2010 and 2011) was usually around 1 percent, and matrix effects, therefore, were not expected to be large. Although the samples analyzed to date have not shown large matrix effects, this could change with different sample matrices_-such as higher organic carbon content water-and strict QA/QC, such as surrogate and matrix spike recoveries, must be adhered to. If the proper QA/QC cannot be met with this method, then other quantification methods, such as standard addition, can be used instead.

\section{Environmental Pesticide Concentrations}

Concentrations of detected pesticides for the sites sampled are shown in table 4. Sope Creek near Marietta, Georgia, which is an urban site with a catchment size of 79.5 square kilometers, had detections of imidacloprid (86 percent detection frequency) throughout the sampling period (October through April); concentrations ranged from 4.5 to $35.3 \mathrm{ng} / \mathrm{L}$, with the highest concentrations detected in winter. Diuron and its degradates DCPMU and 3,4-DCA were
Table 3. Analytical method mean percentage recovery at 20 nanograms per liter ( $\mathrm{ng} / \mathrm{L}$ ) of spike concentration in American River water, relative standard deviation, and method detection limits.

[Abbreviations: RSD, relative standard deviation; MDL, method detection limit; ng/L, nanogram per liter]

\begin{tabular}{lccc}
\hline \multicolumn{1}{c}{ Compound } & $\begin{array}{l}\text { Recovery } \\
\text { (percent) }\end{array}$ & $\begin{array}{c}\text { RSD } \\
\text { (percent) }\end{array}$ & $\begin{array}{c}\text { MDL } \\
\text { (ng/L) }\end{array}$ \\
\hline & Diuron and degradates & \\
\hline Diuron & 94 & 5 & 3.2 \\
DCPU & 83 & 7 & 4.3 \\
DCPMU & 99 & 5 & 3.0 \\
3,4-DCA & 97 & 8 & 5.2 \\
\hline \multicolumn{4}{c}{ Neonicotinoids } \\
\hline Acetamiprid & 91 & 7 & \\
Clothianidin & 93 & 10 & 3.6 \\
Dinotefuran & 75 & 9 & 6.2 \\
Imidacloprid & 97 & 8 & 5.5 \\
Thiacloprid & 89 & 7 & 4.9 \\
Thiamethoxam & 87 & 6 & 3.8 \\
\hline
\end{tabular}

detected less frequently (14, 7, and 36 percent, respectively) than imidacloprid. The highest concentrations of diuron and its degradates occurred in spring (March/April); highest concentration for $87 \mathrm{ng} / \mathrm{L}$ for diuron and $36 \mathrm{ng} / \mathrm{L}$ for 3,4-DCA.

The Chattahoochee River near Whitesburg, Georgia (catchment size 6,290 square kilometers), is downstream of Sope Creek and of Metropolitan Atlanta, and integrates forest, urban and agricultural land uses within its basin. Imidacloprid was detected less frequently (60 percent) in the Chattahoochee River than in Sope Creek (85 percent), and, in general, its concentrations were lower in the Chattahoochee River. Diuron and 3,4-DCA were detected much more frequently (100 and 90 percent, respectively) in the Chattahoochee River; maximum concentrations were $39 \mathrm{ng} / \mathrm{L}$ for diuron and $68 \mathrm{ng} / \mathrm{L}$ for 3,4-DCA. Diuron is primarily used on agricultural crops, and this is reflected by the typically higher concentrations of diuron in the Chattahoochee River than in Sope Creek.

For this data set, 3,4-DCA is the only diuron degradate detected frequently. Because many studies do not measure DCPMU or DCPU in environmental waters, little data are available for comparison. These degradates could be less stable and quickly degrade further, and 3,4-DCA could be more stable. 3,4-DCA was sometimes found at concentrations higher than those of the parent diuron; because 3,4-DCA is also a degradate of two other herbicides, propanil and linuron, there could be other sources. 
Table 4. Dissolved pesticide concentrations measured in samples collected at sites located in Georgia, October 2011 through April 2012.

[Numbers in brackets are U.S. Geological Survey National Water Information System (NWIS) parameter codes. Values are reported in nanograms per liter. Results in parentheses ( ) are below method detection limits and are estimates and have a higher degree of uncertainty. The following compounds were analyzed but were not detected in any samples: acetamiprid, chlothianidin, DCPU, thiacloprid and thiamethoxam. Abbreviations: hh:mm, hours:minutes; ND, not detected]

\begin{tabular}{|c|c|c|c|c|c|c|c|}
\hline $\begin{array}{c}\text { Site name } \\
\text { (USGS Site ID) }\end{array}$ & $\begin{array}{c}\text { Sample } \\
\text { date } \\
\text { (mm-dd-yy) }\end{array}$ & $\begin{array}{c}\text { Time } \\
\text { [hh:mm] }\end{array}$ & $\begin{array}{l}\text { Diuron } \\
\text { [66598] }\end{array}$ & $\begin{array}{l}\text { DCPMU } \\
\text { [68231] }\end{array}$ & $\begin{array}{c}\text { 3,4-DCA } \\
{[66584]}\end{array}$ & $\begin{array}{c}\text { Dinotefuran } \\
\text { [68379] }\end{array}$ & $\begin{array}{c}\text { Imidacloprid } \\
\text { [68426] }\end{array}$ \\
\hline \multirow{13}{*}{$\begin{array}{c}\text { Sope Creek near } \\
\text { Marietta, GA } \\
(02335870)\end{array}$} & $10-04-11$ & $13: 00$ & ND & ND & 3.4 & ND & 17.5 \\
\hline & $10-18-11$ & $13: 00$ & ND & ND & 3.6 & ND & ND \\
\hline & $11-02-11$ & $14: 00$ & ND & ND & ND & ND & ND \\
\hline & $11-17-11$ & $13: 00$ & ND & ND & ND & ND & 8.5 \\
\hline & $12-05-11$ & $13: 00$ & ND & ND & ND & ND & 6.8 \\
\hline & $12-22-11$ & $8: 30$ & ND & ND & ND & ND & 10.4 \\
\hline & 01-05-12 & $14: 00$ & ND & ND & ND & ND & 8.8 \\
\hline & 01-19-12 & $13: 30$ & ND & ND & ND & ND & 35.3 \\
\hline & 02-02-12 & $14: 00$ & ND & ND & ND & ND & 11.0 \\
\hline & 02-14-12 & 9:00 & ND & ND & ND & ND & 4.5 \\
\hline & 03-06-12 & $13: 30$ & ND & ND & ND & ND & 8.6 \\
\hline & 03-22-12 & $10: 30$ & 20.9 & ND & 35.8 & ND & 7.0 \\
\hline & 04-09-12 & $14: 00$ & 86.7 & 7.5 & (1.8) & ND & 6.4 \\
\hline \multirow{10}{*}{$\begin{array}{l}\text { Chattahoochee River } \\
\text { near Whitesburg, GA } \\
\text { (02338000) }\end{array}$} & $10-18-11$ & $10: 30$ & 33.7 & ND & 68.2 & ND & ND \\
\hline & $11-02-11$ & $11: 00$ & 38.9 & ND & 52.4 & ND & ND \\
\hline & $11-17-11$ & $10: 00$ & 27.8 & ND & 12.4 & ND & ND \\
\hline & $12-05-11$ & $10: 00$ & 33.5 & ND & 30.3 & ND & ND \\
\hline & $01-05-12$ & $11: 00$ & 25.9 & ND & 20.4 & ND & 7.9 \\
\hline & 01-19-12 & $10: 00$ & 32.8 & ND & 19.7 & ND & 6.1 \\
\hline & 02-02-12 & $11: 00$ & 13.1 & ND & 26.3 & ND & 4.3 \\
\hline & 03-06-12 & $10: 00$ & 28.5 & ND & 7.2 & ND & 3.4 \\
\hline & $03-22-12$ & $8: 30$ & 10.4 & ND & ND & ND & 7.5 \\
\hline & 04-09-12 & $11: 00$ & 24.8 & ND & 27.5 & (1.6) & 10.1 \\
\hline
\end{tabular}




\section{Analysis of the Herbicide Diuron and Six Neonicotinoid Insecticides in Water-Method Details and Application}

\section{Summary}

This method is appropriate for determining diuron, three diuron degradates, and six neonicotinoid insecticides at low nanogram-per-liter concentrations in natural water by using SPE and LC/MS/MS. This method has been validated with a set of environmental samples and corresponding quality-control samples, which include field replicates, field matrix spikes, and field blanks. Matrix spikes had recoveries of greater than 70 percent for all compounds, and replicate samples had differences less than 20 percent. Diuron and its degradate 3,4-DCA were detected in more than one-half of the stream samples from Georgia, with the majority of detects in the Chattahoochee River (urban and agricultural inputs). Imidacloprid was detected in 74 percent of all the stream samples; 85 percent of the urban samples (Sope Creek) had imidacloprid detects. This method can be used for tracking the environmental fate and transport of these pesticides in water, including those in urban and agricultural areas.

\section{Acknowledgments}

The method development portion of this project was funded by the USGS California Water Science Center with additional instrument funding provided by the USGS Toxics Substances Hydrology Program (Toxics). The Georgia stream sample analyses were funded by the Georgia Department of Agriculture; sample collection was provided by the USGS National Water Quality Assessment (NAWQA).

\section{References Cited}

California Department of Pesticide Regulation, 2010, Pesticide use reporting: accessed June 22, 2012, at http://www.cdpr. ca.gov/docs/pur/purmain.htm.

California Department of Water Resources, 2010, State water project grab sample information: accessed June 22, 2012, at http://www.water.ca.gov/swp/waterquality/GrabSample/ index.cfm.

Chen, W.-H., and Young, T.M., 2008, NDMA formation during chlorination and chloramination of aqueous diuron solutions: Environmental Science and Technology v. 42, no. 4, p. 1072-1077.

Cowles, R.S., 2009, Optimizing dosage and preventing leaching of imidacloprid for management of hemlock woolly adelgid in forests: Forest Ecology and Management v. 257 , no. 3, p. 1026-1033.
Guo, Y.C., Krasner, S.W., Fitzsimmons, S., Woodside, G., and Yamachika, N., 2010, Source, fate, and transport of endocrine disruptors, pharmaceuticals, and personal care products in drinking water sources in California: National Water Research Institute Final Project Report 07-WQ-004, 104p, accessed June 22, 2012, at http://www.nwri-usa.org/ pdfs/NWRIFinalReportEDCsPPCPsMay2010.pdf.

Henry, M., Beguin, M., Requier, F., Rollin, O., Odoux, J.-F., Aupinel, P., Aptel, J., Tchamitchian, S., and Decourtye, A., 2012, A common pesticide decreases foraging success and survival in honey bees: Science v. 336, no. 6079, p. 348-350.

Hladik, M.L., Smalling, K.L., and Kuivila, K.M., 2008, A multi-residue method for the analysis of pesticides and pesticide degradates in water using HLB solidphase extraction and gas chromatography-ion trap mass spectrometry: Bulletin of Environmental Contamination and Toxicology, v. 80, p. 139-144.

Hladik, M.L., Smalling, K.L., and Kuivila, K.M., 2009, Methods of analysis: Determination of pyrethroid insecticides in water and sediment using gas chromatography/mass spectrometry: Techniques and Methods 5-C2, 18 p.

Kreutzweiser, D., Good, K., Chartrand, D., Scarr, T., and Thompson, D., 2007, Non-target effects on aquatic decomposer organisms of imidacloprid as a systemic insecticide to control emerald ash borer in riparian trees . Ecotoxicology and Environmental Safety, v. 68, no. 3, p. 315-325.

Radtke, D.B., revised June 2005, Bottom sample materials, in The national field manual for the collection of water quality data: U.S. Geological Survey Techniques of WaterResources Investigations, book 9, chap. A8,. available at http://pubs.water.usgs.gov/twri9A/.

Smalling, K.L., and Kuivila, K.M., 2008, A multi-residue method for the analysis of current-use and legacy pesticides in sediments and soils:. Journal of Chromatography A 1210, p. 8-18.

Smalling, K.L., Morgan, S., and Kuivila, K.M., 2010, Accumulation of current-use and organochlorine pesticides in crab embryos from Northern California, USA: Environmental Toxicology and Chemistry v. 29, no. 11, p. 2593-2599.

Tixier, C., Bogearts, P., Sancelme, M., Bonnemoy, F., Twagilimana, L., Cuer, A., Bohatier, J., and Veschambre, H., 2000, Fungal biodegradation of a phenylurea herbicide, diuron: Structure and toxicity of metabolites: Pest Management Science, v. 56, p. 455-462. 
Turner, L.T., 2003, Diuron: Analysis of risks to endangered and threatened salmon and steelhead: accessed June 22, 2012, at http://www.epa.gov/oppfead1/endanger/litstatus/ effects/diuron_analysis_final2.pdf.

University of Hertfordshire, 2011, Pesticide properties database, April 2009 version: Agriculture and Environment Research Unit (AERU), Science and Technology Research Institute, University of Hertfordshire, U.K., accessed June 22, 2012, at http://sitem.herts.ac.uk/aeru/footprint/en/ index.htm.

U.S. Environmental Protection Agency, 1997, Definition and procedures for the determination of the method detection limit, app. B, pt.136 of Guidelines establishing test procedures for the analysis of pollutants: U.S. Code of Federal Regulations, Title 40, revised as of July 1, 1997, p. 265-267.

U.S. Environmental Protection Agency, 1998, Status of pesticides in registration, reregistration, and special review: accessed June 22, 2012, at http://www.epa.gov/oppsrrd1/ Rainbow/98rainbo.pdf.

U.S. Environmental Protection Agency, 2003a, Registration eligibility decision (RED) for diuron: accessed June 22, 2012, at http://www.epa.gov/oppsrrd1/REDs/diuron red. pdf.

U.S. Environmental Protection Agency, 2003b, Clothianidin condition registration: accessed June 22, 2012, at http:// www.epa.gov/opprd001/factsheets/clothianidin.pdf.

U.S. Environmental Protection Agency, 2010, Emerging contaminant: N-Nitroso-dimethylamine (NDMA): accessed June 22, 2012, at http://www.epa.gov/fedfac/pdf/technical fact sheet ndma.pdf.
U.S. Environmental Protection Agency, 2011, Pesticide industry sales and usage: 2006 and 2007 market estimates: accessed June 22, 2012, at http://www.epa.gov/ opp00001/pestsales/07pestsales/table of contents2007 2. htm\#pdfreport.

U.S. Geological Survey, 2006, The national field manual for the collection of water quality data, Collection of water samples (ver 2.0): U.S. Geological Survey Techniques of Water Resources Investigations, book 9, chap A4, http:// pubs.water.usgs.gov/twri9A4/.

vanEngelsdorp, D., Evans, J.D., Saegerman, C., Mullin, C., Haubruge, E., Nguygen, B.K., Frazier, M., Frazier, J., Cox-Foster, D., Chen, Y., Underwood, R., Tarpy, D.R., and Pettis, J.S., 2009, Colony Collapse Disorder: A descriptive study: PLoS ONE, vol. 4, no. 8, e6481.

Ward, J.R., and Harr, C.A. eds., 1990, Methods for collection and processing of surface-water and bed-material samples for physical and chemical analyses: U.S. Geological Survey Open-File Report 90-140, 71 p. Available at http://pubs. er.usgs.gov/usgspubs/ofr/ofr90140.

Whitehorn, P.R., O’Connor, S., Wackers, F., and Goulson, D., 2012, Neonicotinoid pesticide reduces bumble bee colony growth and queen production: Science, v. 336, no. 6079, p. 351-352. 
10 Analysis of the Herbicide Diuron and Six Neonicotinoid Insecticides in Water-Method Details and Application

This page is intentionally left blank. 
Publishing support provided by the U.S. Geological Survey Science

Publishing Network, Sacramento and Tacoma Publishing Service Centers

For more information concerning the research in this report, contact the Director, California Water Science Center

U.S. Geological Survey

6000 J Street, Placer Hall

Sacramento, California 95819

http://ca.water.usgs.gov 


\section{罡}

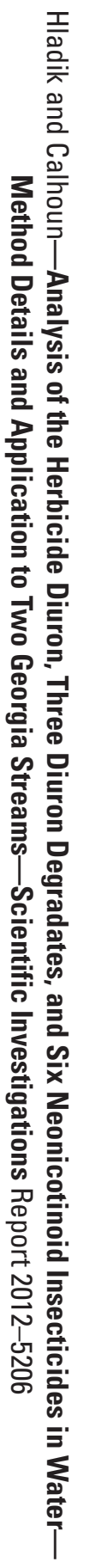

Printed on recycled paper 